\title{
Investigating The Financial Implications Of Alternative Water Heating Systems
}

Anri Pretorius, North-West University, South Africa

Surika van Rooyen, North-West University, South Africa

\begin{abstract}
Electricity tariffs charged by the South African electricity supplier (Eskom) have sharply increased over the past three years and there is no indication of what to expect in the future with regard to electricity tariffs. Many South Africans are searching for ways to save on their monthly electricity bills by seeking out alternative water heating systems. The purpose of this study is to determine the most financially viable alternative water heating system for a household in South Africa using various investment appraisal techniques and taking into consideration the size of the household.

The study found that the five investment options identified in the literature review would all, to some extent, be financially viable to implement within households with high, as well as low, volume hot water consumption. Although some of the water heating systems were found to be more financially viable than others, the conclusion was made that a savings will be generated on the monthly electricity bill no matter what alternative water heating system was to be installed in the place of a conventional geyser.
\end{abstract}

Keywords: Alternative Water Heating Systems; Conventional Geyser; Electricity Cost; Investment Appraisal Techniques; Solar Geyser

\section{INTRODUCTION}

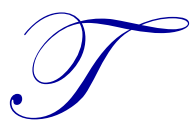

his paper is a qualitative and quantitative investigation into the financial viability of alternative water heating sources available in South Africa. The interest in this topic is that electricity tariffs charged by the South African electricity supplier (Eskom) have sharply increased over the past three years, with a $25 \%$ average annual increase approved by the National Energy Regulator of South Africa (NERSA) until April 2012 (Eskom, 2011a) and 16\% for 2012/2013 (Eskom, 2012). There is no indication of what to expect in the future with regard to electricity tariffs.

Water heating costs within households are the second largest energy cost on the electricity bill, with space heating taking up the biggest part (Hackett \& Gray, 2009). With constant annual rate increases imposed on South African citizens by Eskom, households are being forced to search for alternatives that can reduce the cost of their monthly electricity bill. With this said, house owners are searching for alternative ways to cut operational costs by using natural or renewable energy resources, such as solar geysers, natural gas, or different technologies, such as time switches, heat pumps, or instant heaters.

Considering all the above, the question can be raised, "Which of the mentioned alternatives in water heating systems makes most economic sense?" The research question of this study can therefore be formulated as "What are the household economic implications of key alternative water heating systems within the South African context?"

This research is the first study in South Africa focusing on all the different types of water heating systems available in the market, and not just on a solar geyser or a heat pump. This study focuses on South Africa as a country in a time where alternative water heating systems are highly considered as an alternative to the conventional geyser due to high tariff increases by Eskom. 


\section{BACKGROUND}

Since 1991, one of the South African government's main objectives was to provide access to electricity to the previously disadvantaged communities, increasing the national energy demand significantly (Bredekamp, Uken $\&$ Borrill, 2006). Eskom is, however, unable to immediately increase capacity because it takes between ten to twelve years to build a new power station (Bredekamp, Uken \& Borrill, 2006). To manage this increase, Demandside Management (DSM) was introduced by Eskom, whereby energy consumers are informed about different ways on how to reduce electricity demands. One of which is the Solar Water Heating Programme, whereby incentives are offered to consumers to switch to solar geysers (Eskom, 2010a).

In support of its "Go Green" initiative, Eskom provides a rebate to households when installing a solar geyser. This rebate consists of a percentage of the total cost of the heating system (investment cost plus installation cost). The percentage is calculated on the performance and reliability of the individual system. The more reliable and energy efficient the system, the better the rebate one could claim (Eskom, 2011b). This approach is also followed in countries such as Australia to motivate citizens in the form of a subsidy to install a solar geyser (Hessami, 2006). Solar geysers have become a popular investment option, but the question could be asked whether this is actually the best option available in the market.

\section{THEORY}

\section{Alternative Water Heating Systems}

Five alternative water heating systems were identified for the purposes of this study. These alternative systems could contribute to reducing the electricity consumption of a conventional geyser, either by replacing the conventional geyser or attaching systems to a conventional geyser that could reduce the overall electricity usage.

\section{Solar Geysers}

Solar power results from the conversion of solar energy in the form of light into useable energy, such as electricity or heat. The South African Department of Energy introduced a National Solar Water Heating Program in 2008 whereby they offered subsidies to households installing a solar water heating system in order for them to achieve their one million solar geyser goal by 2014 (Du Toit \& Gilder, 2010). Although solar water heating is an important potential area to take advantage of solar energy, many households consider solar water heating systems as being too expensive due to the high initial investment costs (Kablan, 2003). According to Mohsen and Akash (2002), a solar water heating system is the most beneficial water heating system compared to other options in the market.

The implementation of a solar geyser does not eliminate the usage of electricity with regard to a geyser, but reduces it significantly as the normal geyser will only switch on when the water does not reach the required temperature (Li \& Yang, 2010). Research has shown that solar water heating systems could reduce the monthly electricity cost of a conventional geyser with up to $40 \%$ (Nyatsanza, Davis, Merven \& Cohen, 2008). According to ITS (s.a.), a solar geyser, for a normal household, will repay itself within three to four years after purchase, depending on the location of the household and the hot water consumption of the household. They further state that, under normal circumstances, a solar geyser does not have any maintenance requirements and therefore no maintenance cost. The useful life of a solar geyser is expected to be between 15 and 25 years (PDC Solar, 2008; Home Comfort, s.a). For the purpose of this study, the average useful life of 20 years is used.

\section{Time Switch On A Conventional Geyser}

A time switch is a device that works on an analogue clock alarm that switches a conventional geyser on and off (Talukder, Gholap \& Kanyemba, 2004). When using a time switch on a conventional geyser, one manages the time when the geyser switches on to reheat the water, causing a reduction in the number of times that the geyser element switches on, and therefore reducing the energy consumption of a geyser (Powersaving, 2008). 
The motivation to manage this is because Eskom charges different rates during different times of the day. In peak periods, rates are higher than the rates charged during off-peak periods (Eskom, 2011c). Hot water usage differs from household to household. In most cases, there is a definite peak in energy usage in the morning, late afternoon and evening. Within the daily load profile, $45 \%$ of the daily electricity is used during the late afternoon and evening when, for example, the occupants return from work. These peaks in energy usage may not be solely due to hot water consumption, but it plays an integral part (Bourke \& Bansal, 2010).

In a study by Mayothi (2010), it was found that if the geyser was used on the same principle as a kettle, only supplying hot water when you need it instead of using it like an urn that provides constant boiling water, a savings of up to $25 \%$ of the energy consumption of a conventional geyser could be achieved. The study was conducted on a conventional geyser with no geyser blanket, serving a household of two people, who normally shower/bath in the morning before leaving for work.

Mr J Dreyer (2011), a nuclear engineer at Eskom, who built a heat switching model for the purposes of this study, found that the cost savings due to the installation of a time switch could increase to up to $72 \%$, depending on the number of people in the household.

\section{Heat Pumps}

A heat pump uses heat already available in the atmosphere to generate enough energy to heat up water for domestic use. It works on the same principle as an air conditioning unit, but instead of using it as an air cooling system with heat as a by product, the focus is on utilising the heat to generate hot water (Van Eldik, 2008). The energy savings is due to the fact that the heat pump not only uses a heating element, but also uses the outdoor air temperature to produce hot water; therefore, less electricity is needed to bring the water to the preferred temperature (M-Tech Industrial (Pty) Ltd., 2002). The energy efficiency of a heat pump is dependent on climate conditions (Lienau, Boyd \& Rogers, 1995; Kim, Kim \& Chung, 2004).

A conventional geyser is a convenient way of water heating with regard to installation and operation, but the energy efficiency of a conventional geyser is very low in comparison to a heat pump, as a heat pump can supply more heat using the same amount of electricity (Kim et al., 2004). According to Fardoun, Ibrahim and Zoughaib (2011), the use of an air source heat pump can reduce the electricity usage on a conventional geyser by $70 \%$. This is in agreement with GEO plus's (2006) statement that a heat pump can save up to two thirds of the energy consumption of a conventional geyser.

Eskom offers a rebate on the installation of a heat pump (Eskom, 2010c). The rebate depends on the size of the heat pump installed. One can expect a rebate of R4 $320(\mathrm{R}=$ South African Rand $)$ for a tank size between 300 and 500 litres, and a R3 668 rebate for a tank size between 100 and 300 litres (Eskom, 2010c). According to a study done by Cane, Morrison and Ireland (1998), the service and maintenance costs associated with a heat pump are significantly lower than the service and maintenance cost on a conventional geyser.

\section{Gas Geysers}

Gas water heaters are a storage type water heater that constantly maintains the water temperature during the day (Aguilar, White \& Ryan, 2005). A gas geyser is similar to a conventional geyser; the only difference is that the water is not heated by an electric element, but through a gas burner at the bottom of the tank, eliminating the use of electricity (Formisano, 2006). The gas burner switches on when the water temperature drops below a certain point, and automatically switches off once the water reaches the high temperature limit (American Council for an EnergyEfficient Economy (ACEEE), 2007).

The gas water heater heats the water faster, saves on energy consumption, therefore cutting on energy costs (Aguilar et al., 2005). A gas geyser's useful life is expected to be around twelve years if maintained properly (Kablan, 2004). 
The installation costs associated with a gas geyser are dependant on the scale of work needed, the piping required and all the fittings, connections, regulator, etc. needed for proper functioning of the gas geyser (The Gas Experts, 2009). The monthly gas consumption amounts to an average cost of around R320, dependent on the volume of hot water consumption, and electricity cost is completely eliminated (Geyser, 2011). Oorja Solutions (s.a.) calculated the monthly gas expenses of a gas geyser in India, and found that the cost of gas associated with a gas geyser is around $25 \%$ of the total cost of the electricity cost associated with a conventional geyser. They also state that the only maintenance cost on a gas geyser will be when the gas supply hose is damaged and needs to be replaced, which is a minimal cost.

\section{Instant Heaters}

Instant heaters, otherwise known as tankless water heaters, heat water as you need it, without storing a hot water supply and constantly heating and re-heating water to keep it at a preferred temperature (Lingro Gas Appliances, s.a.). Tank type water heaters constantly need to switch on to maintain the required water temperature, even if no hot water is used, increasing the unnecessary use of electricity or gas, where an instant heater only supplies the hot water demand without storing any hot water (Orloff, s.a.).

An instant heater is a small unit not much bigger than a normal laptop that is mounted to a wall. Therefore, this alternative is a space-saving option when considering water heating systems (Jamee, 2011). Conventional geysers tend to leak after a while due to water storage and could cause damage to the property, whereas an instant heater does not cause such damages as it does not store any water. Stroozas (2007) mentions that an instant heater reduces the energy losses due to standby hot water in the storage tank waiting to be used. He also states that instant heaters reduce the water wastage due to running taps waiting for the hot water coming from storage tanks, and that this type of water heater work extremely well within the food services industry where the demand for hot water is high.

Instant heaters can generate an energy savings of between 27 and $50 \%$ of the total cost associated with a conventional geyser if installed on each hot water outlet within a household in the United States (United States Department of Energy, 2011). Currently, this is the best indication of what the electricity savings will be, as instant water heaters are not that well known in South Africa as yet.

For the purpose of this study, only two instant water heaters will be installed in the household, one in the kitchen and one in the bathroom. By taking the hot water usage spread within a household into consideration, the savings will be generated in two areas, which contribute $51 \%$ of the total hot water consumption within the household. Therefore, if the maximum energy savings generated if instant water heaters were installed on all hot water outlets is $50 \%$ of the total energy cost of a conventional geyser, the energy savings for the purposes of this study will be $25 \%(50 \%$ of $51 \%$ ). This is because the instant heaters will only serve hot water outlets that supply $51 \%$ of the total hot water consumption.

The useful life of an instant heater is expected to be around 20 years, but the useful life can be extended if maintained properly (United States Department of Energy, 2011).

\section{Investment Appraisals}

Cicea, Vasilescu, and Banacu (2009) state that investors will not consider investing in any investment unless it is profitable. In order to determine the profitability of an investment, management accounting and financial management offer different methods of calculating the financial impact of different investments, by using different investment appraisal techniques.

The main objective of an investment appraisal is to calculate, from the forecasted cash flows, whether the investment will be suitable for the investor (Laurentiu, 2010). Laurentiu (2010) also states that if there is more than one investment option, investment appraisals are used to rank the investment options. According to Savvides (1994), the first step in conducting an investment appraisal is to utilise information gathered of a certain type of investment in the past to predict what will happen if the same investment takes place in the future. This is a process 
of forecasting, whereby the best possible estimates are calculated that will be used as inputs into the appraisal analysis.

For private investments, the financial cash flows can be defined as the investment inputs and outputs calculated on the market price (Foltyn-Zarychta, 2010:290). The market price represents the price of an investment on the open market at any given time (Garrison, Noreen \& Brewer, 2008). The higher the capital requirement of a project, the higher the profitability of the project needs to be to make it worthwhile for the investor to invest in the investment option (Stalder, Lacy, Cross, Conatser \& Darroch, 2000).

The traditional methods of investment appraisal applied in this study include the following: net present value (NPV), internal rate of return (IRR), modified internal rate of return (MIRR), discounted payback period economic value added (EVA).

\section{DESIGN AND METHOD}

\section{Research Objectives}

The general objective of this research is to determine the most financially viable investment to reduce electricity cost when it comes to water heating systems for use in households by comparing the capital expenditure and operational cost needed with the financial benefits generated by the investment, taking into consideration the size of the household.

The specific objectives of this study are:

- to consider, within the context of high-volume hot water consumption households, the investment cost, net present value, equivalent annual annuity, internal rate of return, modified internal rate of return, discounted payback period, and economic value added for a solar water heating system, a time switch on a conventional geyser, a heat pump, a gas geyser, and an instant heater

- $\quad$ to consider, within the context of low-volume hot water consumption households, the investment cost, net present value, equivalent annual annuity, internal rate of return, modified internal rate of return, discounted payback period, and economic value added for a solar water heating system, a time switch on a conventional geyser, a heat pump, a gas geyser, and an instant heater

- $\quad$ to provide recommendations regarding the most financially viable water heating system for a household, depending on the volume of hot water consumption

\section{Research Design}

This study can be classified as an empirical study using primary numeric and textual data with a low level of control (Mouton, 2010). The data used in the investment appraisals were gathered through several quotations and therefore represent new data. However, some of the data used were gathered through existing sources. This will, however, still keep the control on this study low, meaning that if another individual were to do the same study, the outcome would not necessarily be the same as they would not get the same quotations from suppliers and might make other assumptions from the results of the investment appraisals. A mixed method approach was followed comprising of qualitative and quantitative methods (Mouton, 2010; Maree, 2010). In a mixed approach, the qualitative findings help the researcher develop an understanding of the quantitative findings (Maree, 2010).

\section{Determining The Financial Viability Of Alternative Water Heating Systems}

Five alternative water heating systems were evaluated in this research study. These systems are the solar geyser, time switch on a conventional geyser, heat pump, gas geyser and an instant heater. Each of the alternatives for water heating generates a savings in electricity usage on a conventional geyser to some extent, and therefore will generate a cost savings for the investor. Various investment appraisal techniques were used in order to measure the financial viability of each of the selected alternative water heating systems. The techniques applied included net present value (NPV), equivalent annual annuities (EAA), internal rate of return (IRR) and modified internal rate of return (MIRR), discounted payback period and economic value added (EVA). 
Other considerations taken into account in determining the financial viability of the alternative water heating systems were as follows:

Inflation

Inflation was taken into account for the purpose of this study. The inflation rate was used to determine the price increase of electricity from 2013 onwards. The reason for this is that, up to this point, Eskom only has permission to increase electricity charges by 25\% until 2012 (NERSA, 2009) and 16\% for 2012/2013 (Eskom, 2012). No indication is available of what will happen from 2013 onwards; therefore, the inflation rate seems to be the realistic view. The rate that was used is $10 \%$, which represents the average inflation rate between 1981 and 2010 (Trading Economist, 2011).

\section{Household Size And Water Consumption}

The investment appraisals were performed to determine the best investment option for a household with low-volume hot water consumption and a household with high-volume hot water consumption. From the literature, it was determined that an average of four people stay in a household with low-volume hot water consumption and that an average of six people stay in a household with high-volume hot water consumption (FinScope, 2009). A study done by Meyer (2000) indicates that the average hot water usage per person in South Africa is 60 litres per day.

\section{Average Electricity Usage}

The average electricity usage per month was calculated by Mr J Dreyer (Dreyer, 2011) by using the heat switching model that was developed for this study. To determine the electricity usage per month, the assumption was made that the 60 litres of hot water consumption per person per day are spread over the day. A table by Bourke and Bansal (2010) was used in the heat switching model to determine how much electricity is used to heat water for domestic use.

Eskom charges block tariffs dependent on the kWh used; the more $\mathrm{kWh}$ one uses, the higher the rate charged (Eskom, 2010b). Mr Dreyer used the block tariffs charged by Eskom for residential users in order to calculate the monthly electricity cost. To determine the annual electricity cost, the monthly cost was multiplied by 12.

By taking inflation into account, the annual electricity cost of a conventional geyser was calculated by using the annual cost of a conventional geyser, as calculated by Dreyer in his heat switching model, and then increasing it in 2012 with 25\%, 16\% in 2013 and from 2014 onwards by $10 \%$.

\section{Costs}

Costs represent any outflow of cash at the beginning, or during the investment assessment period used to fund and maintain the investment (Adhikari \& Supakankunti, 2010). These costs include the initial investment costs, the installation costs associated with each investment option, as well as maintenance costs and any additional costs.

The investment cost of each alternative water heating system was determined by calculating the average investment cost from three quotations received. The quotations were gathered from suppliers of hot water heating systems. Included in the quotation is the installation cost associated with the investment, as this forms an integral part of the investment appraisal. The investment cost takes place in year 0 , as the total amount needs to be paid immediately in order to install the hot water heating system.

Eskom only grants a rebate on the installation of a solar geyser and a heat pump. This rebate is included as a separate line at the bottom of all the quotations received for these two options, but not taken into account within the investment cost section of this study; therefore, the average rebate is calculated. 
A gas geyser saves $100 \%$ on energy consumption of a conventional geyser, but in order to do this, the electricity is replaced by the use of gas. The cost of the gas usage was included under costs.

\section{Cost Savings}

An important part of the analysis is to calculate the cost per kWh of energy saved by implementing the five different investment options, as this forms an integral part of the cost benefit analysis (Olivier, Harms \& Esterhuyse, 2008). The cost savings calculation was performed by making use of the heat switching module created by Dreyer, whereby the per capita usage of a household was determined. From there, the energy savings per scenario was calculated and the correct rand value per $\mathrm{kWh}$ was used to determine accurate benefit estimations. The cost savings included were mainly the savings generated due to the reduction in electricity consumption by each of the five investment options.

This represents a percentage of the electricity consumption of a conventional geyser. For the purposes of this study, these savings are based on previous research as discussed in the previous section.

\section{Useful Lives}

The useful life represents the expected time it will take before the hot water heating systems will need replacement. Each of the five hot water heating systems evaluated in this study has different useful lives. Each investment option is evaluated over its useful life, and not at a set number of years.

When investments have unequal lives, it becomes difficult to accurately evaluate and compare the different investments, and incorrect ranking of options could occur (Pilotte, 2000). The main issue with investments with different life spans is that there will be different options at different dates in the future, which might have different values and might affect the choices made by the investor (Brown \& Davis, 1998; Correia, Flynn, Uliana \& Wormald, 2010). Brown and Davis (1998) as well as Correia et al. (2010) suggest that a possible solution to this problem is to compare the infinite NPV, also known as equivalent annual annuities (EAA), of each investment. Therefore, the equivalent annual annuity for each investment option in this study was calculated and compared.

\section{Discount Rate}

The discount rate for individuals differs from person to person, depending on his/her financing preference. Foltyn-Zarychta (2010) states that the market discount rate has to be used to evaluate investments for private investors. For the purposes of this study, the assumption is made that, in South Africa, the prime rate represents the market discount rate. The current prime rate in South Africa of 9\% (Absa, 2012) is used as the discount rate.

\section{EMPIRICAL RESULTS}

The empirical study focused on project appraisals of the five investment options identified. This includes an investment appraisal for a household with low-volume hot water consumption and a household with high-volume hot water consumption within an urban environment. In performing these investment appraisals, the net present value, equivalent annual annuity, internal rate of return, modified internal rate of return, discounted payback period and economic value added of the investments were determined.

\section{Household With Low-Volume Hot Water Consumption}

Table 1 shows the summary of results of the investment appraisal calculations that were performed on each of the alternatives for a household with low-volume hot water consumption. 
Table 1: Results For A Household With Low-Volume Hot Water Consumption

\begin{tabular}{|l|l|l|l|l|l|}
\hline & \multicolumn{1}{|c|}{ Solar Geyser } & \multicolumn{1}{|c|}{ Time Switch } & \multicolumn{1}{c|}{ Heat Pump } & \multicolumn{1}{c|}{ Gas Geyser } & \multicolumn{1}{c|}{ Instant Heater } \\
\hline NPV & R63 750 & R49 410 & R91770 & R59610 & R62 840 \\
\hline EAA & R6 984 & R7 699 & R11385 & R8 325 & R4 693 \\
\hline IRR & $33 \%$ & $354 \%$ & $71 \%$ & $60 \%$ & $43 \%$ \\
\hline MIRR & $18 \%$ & $55 \%$ & $26 \%$ & $26 \%$ & $20 \%$ \\
\hline $\begin{array}{l}\text { Discounted Payback } \\
\text { Period }\end{array}$ & 4.49 years & 0.30 years & 1.78 years & 2.15 years & 3.23 years \\
\hline EVA & R66 760 & R50 070 & R94 940 & R64 000 & R44 180 \\
\hline
\end{tabular}

For a household with low-volume hot water consumption, the most financially viable alternative water heating system is a time switch on a conventional geyser. Although the NPV and equivalent annual annuity of this investment option are not the highest between the options, it renders the best IRR, MIRR, and discounted payback period. The IRR of a time switch is almost five times higher than the investment option with the second highest IRR, the MIRR at 2.12 times and the discounted payback period at 5.9 times quicker.

The second best investment option for a household with low-volume hot water consumption will be a heat pump. This investment option has the highest NPV, equivalent annual annuity, and EVA, with the second highest IRR, MIRR, and discounted payback period.

A gas geyser will be the third best investment option for a household with low-volume hot water consumption.

\section{Household With High-Volume Hot Water Consumption}

See Table 2 for results of a household with high-volume hot water consumption.

Table 2: Results For A Household With High-Volume Hot Water Consumption

\begin{tabular}{|l|l|l|l|l|l|}
\hline & \multicolumn{1}{|c|}{ Solar Geyser } & \multicolumn{1}{|c|}{ Time Switch } & \multicolumn{1}{c|}{ Heat Pump } & \multicolumn{1}{c|}{ Gas Geyser } & \multicolumn{1}{c|}{ Instant Heater } \\
\hline NPV & R90 370 & R79 040 & R125 900 & R98 080 & R59480 \\
\hline EAA & R9 900 & R12 316 & R15619 & R13697 & R6516 \\
\hline IRR & $42 \%$ & $554 \%$ & $91 \%$ & $87 \%$ & $54 \%$ \\
\hline MIRR & $20 \%$ & $62 \%$ & $29 \%$ & $31 \%$ & $22 \%$ \\
\hline $\begin{array}{l}\text { Discounted payback } \\
\text { period }\end{array}$ & 3.39 years & 0.20 years & 1.34 years & 1.41 years & 2.44 years \\
\hline EVA & R93 380 & R79690 & R129 080 & R102 470 & R60 820 \\
\hline
\end{tabular}

For a household with high-volume hot water consumption, the most financially viable alternative water heating system is, again, a time switch, with the highest IRR, MIRR and discounted payback period. The NPV and equivalent annual annuity for a time switch increased significantly from the investment appraisal for a time switch for a household with low-volume hot water consumption, making it more competitive in that area with the other options. The IRR is six times more than the option with the second highest IRR, the MIRR is double that of the second best option and the discounted payback period is 6.7 times quicker.

The second best investment option for a household with high-volume hot water consumption is again a heat pump, with the highest NPV, equivalent annual annuity and EVA, and the second highest IRR and discounted payback period. The gas geyser is the third best investment option for a household with high-volume hot water consumption.

\section{CONCLUSION}

The main objective of this study was to determine the most financially viable investment to reduce electricity cost when it comes to alternative water heating systems for use in households taking into consideration the size of the household. 
The study found that a savings would be generated on the monthly electricity bill, no matter which of the identified alternative water heating systems were installed in the place of a conventional geyser. The study was performed for a household with low hot water consumption as well as a household with high hot water consumption. In both cases, it was found that the most financially viable option would be to install a time switch on the conventional geyser. The second best alternative for both scenarios would be a heat pump, and the gas geyser is the third best alternative.

As a result of the findings, the study concludes that these five alternatives outperform the conventional geyser. The practical implication is that South African households should adopt alternative water heating systems in order to save on their monthly electricity bills. From this study, it is evident that the government and Eskom should also do more to create an awareness of the different alternatives available.

This is the first research focusing on all the different types of water heating systems, and not just on a solar geyser or a heat pump. This study focuses on South Africa as a country in a time where alternative water heating systems are highly considered due to high tariff increases by Eskom.

The contribution of this study is that it provides a detailed financial analysis of each of the water heating systems and compares all five alternative water heating systems by considering various investment appraisal techniques.

The following limitations regarding this study should be considered:

- $\quad$ Limited literature is available on the different hot water heating systems, which made it difficult to perform a proper literature review on all aspects of these systems.

- $\quad$ No indication could be given on the maintenance costs of a conventional geyser, as well as all the other water heating systems. Therefore, the assumption had to be made that the maintenance cost is not significant, and therefore this cost was not included in the investment appraisals.

- The situation differs from individual to individual. The assumption is made that they are mostly in a net lending position, and therefore the prime lending rate was used as a discount rate.

In future research, the population of this study could be focused on small businesses and large organizations. Future research could also include the most appropriate discount rate for individuals as well as the maintenance cost of the alternative water heating systems.

\section{AUTHOR INFORMATION}

Anri Pretorius completed a BCom in Management Accounting at the North-West University (Potchefstroom). She completed her honours degree in Management Accounting at the end of 2008 and enrolled for a master's degree in Management Accounting in 2009, which she completed in 2012. Anri has completed all the relevant examinations for an international Management Accounting qualification through the Chartered Institute of Management Accountants (CIMA) and will register as a Chartered Management Accountant as soon as the required practical experience is gained. She currently works at Absa Bank as a cost and profitability analyst, mainly focusing on transfer pricing.

Professor Surika van Rooyen is currently an associate professor at the North-West University (South Africa). She holds the Chartered Accountant (CA (SA)) designation and a master's degree in financial management (Cum Laude). She has lectured at various levels of complexity and received various outstanding educator awards, including an award for the best lecturer in the Faculty of Economic and Managements Sciences. She also received the award as the best master's degree student in the School of Accounting Sciences in 2005. She is also the coauthor of various publications in financial management in peer-reviewed journals. E-mail: Surika.Vanrooyen@nwu.ac.za (Corresponding author) 


\section{REFERENCES}

1. Absa. (2012). Indices. Retrieved from: http://www.absa.co.za/Absacoza/Indices/Prime-Rate Accessed on January $10^{\text {th }}, 2012$.

2. ACEEE (The American Council for an Energy-Efficient Economy). (2007). Emerging Technologies Report: Residential Boiler Controls, May 2006. Retrieved from: http://aceee.org/files/pdf/2006_BoilerControls.pdf Accessed on July 5 ${ }^{\text {th }}, 2011$.

3. Adhikari, S.R. \& Supakankunti, S. (2010). A cost benefit analysis of elimination of kala-azar in Indian subcontinent: an example of Nepal. Journal of Vector Borne Diseases, 43:127-139, September.

4. Aguilar, C., White, D.J. \& Ryan, D.L. (2005). Domestic water heating and water heater energy consumption in Canada. Retrieved from: http://www.ualberta.ca/ cbeedac/publications/documents/domwater_000.pdf Accessed on July $25^{\text {th }}, 2011$.

5. Bourke, G. \& Bansal, P. (2010). Energy consumption modeling of air source electric heat pump water heaters. Applied Thermal Engineering, 30:1769-1774.

6. Bredekamp, A.J., Uken, E.A. \& Borrill, L. (2006). Standby power consumption of domestic appliances in South Africa. Domestic use of energy conference. Retrieved from: http://www.myprius.co.za/D04\%2010\%20-\%20\%20Bredekamp\%20A.pdf Accessed on July 11th, 2011.

7. Brown, C. \& Davis, K. (1998). Options in mutually exclusive projects of unequal lives. The quarterly review of economic and finance, 38:569-577.

8. Cane, D., Morrison, A. \& Ireland, C.J. (1998). Maintenance and service costs of commercial building ground-source heat pump systems. Retrieved from: http://www.wfiglobal.com/documents/research/7-4.pdf Accessed on September 19 2011.

9. Cicea, C., Vasilescu, I. \& Banacu, C. (2009). Direct investment analysis, starting point to attract new investors in economy: a macrosystemic approach. Communications of the IBIMA, 7:92-96.

10. Correia, C., Flynn, D., Uliana, E. Wormald, M. (2010). Financial management. $7^{\text {th }}$ ed. Cape Town: Juta $\&$ Co.

11. Du Toit, L. \& Gilder, A. (2010). Country profile: South Africa. Carbon \& Climate Law Review, 4:386391.

12. Dreyer, J. (2011). Heat transfer model [E-mail]. November $29^{\text {th }}$, 2011. Johannesburg.

13. ESKOM. (2010a). Learn about IDM. Retrieved from: http://www.eskomidm.co.za/home/about Accessed on July $11^{\text {th }}, 2011$.

14. ESKOM. (2010b). Inclining block rate tariff explanation. Retrieved from: http://www.eskom.co.za/content/IncliningblocktariffexplanationIssue32010.pdf Accessed on January $5^{\text {th }}$, 2012.

15. ESKOM. (2010c). Eskom IDM - Heat pumps. Retrieved from: http://www.eskomidm.co.za/heat-pumps Accessed on November $6^{\text {th }}, 2011$.

16. ESKOM. (2011a). Eskom retail tariff adjustment for 2011/2012. Retrieved from: http://www.eskom.co.za/content/201112\%20Price\%20increase.pdf Accessed on February 22 ${ }^{\text {nd }}, 2013$.

17. ESKOM. (2011b). Solar water heating supplier list. Retrieved from: http://www.eskomidm.co.za/residential/residential-technologies/solar-water-heating-supplier-list Accessed on May $31^{\text {st }}, 2011$.

18. ESKOM. (2011c). NERSA-approved price increase for the multiyear pricing determination (MYPD) 2 process (2010-2013). Retrieved from: http://www.eskom.co.za/live/content.php?Category_ID=26 Accessed on March $20^{\text {th }}, 2011$.

19. ESKOM. (2012). Tariffs and charges. Retrieved from: http://www.eskom.co.za/c/53/tariffs-and-charges/ Accessed on February $28^{\text {th }}, 2013$.

20. Fardoun, F., Ibrahim, O. \& Zoughaib, A. (2011). Quasi-steady state modelling of an air source heat pump water heater. Science Direct, 6:325-330.

21. Finscope. (2009). Press release: South Africa in black and white. Johannesburg: FinMark \& TNS Research Surveys. Retrieved from: http://www.finscope.co.za/documents/2009/PRFS08_sa.pdf Accessed on February 13 ${ }^{\text {th }}, 2012$.

22. Foltyn-Zarychta, M. (2010). Discounting in intergenerational project appraisal-efficient versus just decision making. Scientific Annals of the Alexandru Loan Cuza University of Iasi: Economic Sciences Series, LVII (2010):289-302. 
23. Formisano, B. (2006). Anatomy of a gas water heater (tank type). Retrieved from: http://homerepair.about.com/od/plumbingrepair/ss/hwh tank gas.htm Accessed on July $5^{\text {th }}, 2011$.

24. Garrison, R.H., Noreen, E.W. \& Brewer, P.C. (2008). Managerial accounting. $12^{\text {th }}$ ed. New York: McGraw-Hill/Irwin.

25. GEO Plus. (2006). Energy savings and economic viability of heat pumps investigated. Retrieved from: http://www.geoplus.co.za/index.php/the-news/45-an-investigation-into-the-energy-savings-and-economicviability.pdf Accessed on September $19^{\text {th }}, 2011$.

26. Geyser, T. (2011). Quotation QT 20259 [E-mail]. September $8^{\text {th }}$, 2011. Johannesburg.

27. Hackett, M.J. \& Gray, N.F. (2009). Carbon dioxide emission savings potential of household water use reduction in the UK. Journal of Sustainable Development, 2(1):36-43.

28. Hessami, M. (2006). Designing a hybrid wind and solar energy supply system for a rural residential building. International Journal of Low Carbon Technologies, 1/2:112-126.

29. Home Comfort. s.a. Solar heating. Retrieved from: http://www.homecomfort.co.za/solar-heating.html Accessed on January $10^{\text {th }}, 2012$.

30. ITS. s.a. Solar geyser \& solar water heating questions \& answers. Retrieved from: http://www.solargeysers-sa.co.za/Solar-Water-Heating-Questions.asp\#5 Accessed on September 17 $7^{\text {th }}, 2011$.

31. Jamee, K. (2011). Tankless water heaters: the future of water heating. Retrieved from: http://www.articlecell.com/Article/Tankless-Water-Heaters---The-Future-of-Water-Heating/951579 Accessed on July $26^{\text {th }}, 2011$.

32. Kablan, M.M. (2003). Forecasting the demand on solar water heating systems and their energy savings potential during the period 2001-2005 in Jordan. Energy Conversion and Management, 44:2027-2036.

33. Kablan, M.M. (2004). Techno-economic analysis of the Jordanian solar water heating system. Energy, 29:1069-1079.

34. Kim, M., Kim, M.S. \& Chung, J.D. (2004). Transient thermal behavior of a water heater system driven by a heat pump. International Journal of Refrigeration, 27:415-421.

35. Laurentiu, D. (2010). Financial indicators for the implementation of a European funded investment project under SOP IEC programme - case study of a Romanian SME. Annals of the University of Oradea: economic science, 1:344-350.

36. Li, H. \& Yang, H. (2010). Energy and energy analysis of multi-functional solar-assisted heat pump system. International Journal of Low-Carbon Technologies, 5:130-136.

37. Lienau, P.J., Boyd, T.L. \& Rogers, R.L. (1995). Ground-source heat pump case studies and utility programs. Retrieved from: http://geoheat.oit.edu/pdf/hp1.pdf Accessed on June 27 ${ }^{\text {th }}, 2011$.

38. Lingro Gas Appliances. s.a. Tankless water heaters. Retrieved from: http://www.linrogas.co.za/pdf/gasinfo.pdf Accessed on June 27 ${ }^{\text {th }}, 2011$.

39. Maree, K. (2010). First steps in research. Pretoria: Van Schaik Publishers.

40. Mouton, J. (2010). How to succeed in your master's \& doctoral studies. Pretoria: Van Schaik Publishers.

41. Mayothi. (2010). Can you save electricity by switching your geyser off on a daily basis? Retrieved from: http://www.mayothi.com/geyser.html Accessed on September $17^{\text {th }}, 2011$.

42. Meyer, J.P. (2000). A review of domestic hot-water consumption in South Africa. $R \& D$ Journal, 16(3):55-61.

43. Mohsen, M.S. \& Akash, B.A. (2002). On integrated solar water heating system. Int. Comm. Heat Mass Transfer, 29(1):135-140.

44. M-Tech Industrial (Pty) Ltd. (2002). Heat pump water heaters for energy efficient water heating at centralized sanitary water heating systems. Retrieved from: http://www.enerflow.co.za/downloads/MTech\%20Heat\%20pump\%20case\%20study.pdf Accessed on June $27^{\text {th }}, 2011$.

45. NERSA (National Energy Regulator of South Africa). (2009). Indicative future Eskom price direction: real 2008/09 prices after 31.3\% increase in 2009/10. Retrieved from: http://www.nersa.org.za/ Accessed on September 16 $6^{\text {th }}, 2011$.

46. Nyatsanza, K.S., Davis, S.J., Merven, B. \& Cohen, B. (2008). Modeling the impact of energy efficiency initiatives in the South African residential sector. Retrieved from: http://active.cput.ac.za/energy/web/due/papers/Conference\%20Presentations/Papers/Paper\%20$\% 20 \mathrm{~K} \% 20$ Nyatsanza.pdf Accessed on July $25^{\text {th }}, 2011$. 
47. Olivier, J.R., Harms, T.M. \& Esterhuyse, D.J. (2008). Technical and economic evaluation of the utilization of solar energy at South Africa's SANAE IV base in Antarctica. Renewable Energy, 33:10731084.

48. Oorja Solutions. s.a. Gas geysers. Retrieved from: http://www.oorjasolution.com/gas_geyser.html Accessed on September 19 $19^{\text {th }}, 2011$.

49. Orloff, J. s.a. How tankless water heaters save energy. Retrieved from: http://saveenergy.about.com/od/productreviews/p/Tankless_Water.htm Accessed on July 5 th $^{2011 .}$

50. PDC Solar. (2008). Subsidised solar geysers selling fast. Retrieved from: http://www.pdcsolar.co.za/2/solar-water-heaters-in-south-africa-make-sense-with-an-eskom-backedsubsidy / Accessed on March $13^{\text {th }}, 2012$.

51. Pilotte, E.A. (2000). Evaluating mutually exclusive projects of unequal lives and differing risks. Financial practice and education, 101-105. Fall/Winter.

52. Powersaving. (2008). Switching your geyser off and automatic time switches. Retrieved from: http://www.powersaving.co.za/index.php?q=con,47,\%20Power\%20Saving Accessed on July $25^{\text {th }}, 2011$.

53. Savvides, S.C. (1994). Risk analysis in investment appraisal. Project appraisal journal, 9(1); 1-30.

54. Stalder, K.J., Lacy, R.C., Cross, T.L., Conatser, G.E. \& Darroch, C.S. 2000. Net present value analysis of sow longevity and the economic sensitivity of net present value to changes in production, market price, feed cost, and replacement gilt costs in a farrow-to-finish operation. The professional animal scientist, $16: 33-40$.

55. Stroozas, T. (2007). Straight talk about tankless water heaters. Can they really keep you in hot water? Retrieved from: http://www.gfen.com/pdf/articles/cookinggas1207.pdf Accessed on July $26^{\text {th }}, 2011$.

56. Talukder, H.M., Gholap, A.V. \& Kanyemba, S. (2004). Design and construction of a water heater controller. African Journal of Science and Technology: Science and Engineering Series, 5(1):1-5.

57. The Gas Experts. (2009). Installation \& regulations. Retrieved from: http://www.gasexperts.co.za/Installation.htm Accessed on September 19 $9^{\text {th }}, 2011$.

58. Trading Economist. (2011). South African inflation rate. Retrieved from: http://www.tradingeconomics.com/south-africa/inflation-cpi Accessed on September 14 ${ }^{\text {th }}, 2011$.

59. United States Department of Energy. (2011). Demand (tankless or instantaneous) water heaters. Retrieved from: http://www.energysavers.gov/your_home/water heating/index.cfm/mytopic=12820 Accessed on July $26^{\text {th }}, 2011$.

60. Van Eldik, M. (2008). How does a heat pump water heater work? Retrieved from: http://www.mtechindustrial.com/products/enerflow heatpumps/02how does heatpump_work.html Accessed on June $27^{\text {th }}, 2001$. 